\title{
URGENSI PROGRAM SIARAN PADA LEMBAGA PENYELENGGARA PENYIARAN
}

\author{
Juniawati
}

\begin{abstract}
ABSTRAK
Pendengar adalah konsumen produk siaran. Hal ini sudah tentu membuat ritme kerja dari sebuah lembaga tersebut lebih fokus dan lebih berkonsentrasi dam memperhatikan proses awal hingga produk siaran diterima khalayak. kebutuhan khalayak makin berkembnag dengan keadaan terkini yang terjadi pada masyarakat yang terus berubah. Maka tidak heran, apabila program siaran tidak sepenuhnya dapat berjalan secara mulus. Bisa saja memunculkan kegagalan dalam proses pelaksanaannya. Disinilah dinamikanya. Kemungkinan akan muncul banyak spekulasi ketika keputusan yang dikeluarkan dalam pengaturan program siaran. Namun bagaimanapun upaya tersebut baik dilakukan untuk memperbaiki sekaligus meningkatkan mutu program siaran. Karena itu membuat progam siaran tidak mesti berpacu pada satu aspek, bisa saja banyak aspek yang dipertimbangkan media penyiaran. Kembali bagaimana langkah strategis yang diambil oleh media penyiaran dalam menata program siarannya.
\end{abstract}

Kata Kunci: siaran, khalayak

\section{A. Pendahuluan}

khalayak merupakan sasaran utama dari media cetak maupun elektronik. Posisi khalayak sangat dipentingkan oleh suatu media. Kebutuhan khalayaklah yang kemudian menjadi dasar pijakan utama dalam menentukan strategi media. dalam kesempatan ini penulis ingin menjelaskan bahwa media elektronik televisi dan radio sangat bergantung pada khalayak dengan memprioritaskan out put dari penyiaran berdasarkan kepada kebutuhan khalayak.
Khalayak atau pembeli utama dari produk yang dihasilkan media siaran, boleh jadi penentu maju dan mundurnya sebuah stasiun siaran. Demikian pula dengan eksistensi media elektronik, sedikit banyak menggantungkan dirinya pada kesediaan khalayak sebagai pengguna utama dari karya yang diciptakan oleh media penyiaran.

Pada umumnya di negara-negara berkembang, hal ini sangat diperhatikan. Berbagai cara dibuat untuk mengalihkan 
perhatian khalayak hanya pada program yang dibuat media siaran. Seiring dengan itu, sikap khalayak dalam perkembangan zaman, senantia mengalami perubahan. Seperti ditunjukkan ketika, masa sebelum reformasi, sikap khalayak penyiaran masih terbilang fasif, namun begitu memasuki masa reformasi dan dunia penyiaran diberi angin segar dengan kebebasan berekspresi dan berimprovisasi.

Hal ini secara tidak langsung telah mendorong masyarakat menjadi lebih atraktif dan dinamis. Alhasil, media memperoleh rating tertinggi, manakala eksistensinya diakui oleh khalayak dan sebaliknya dan tanpa disadari, keadaan ini menjadi pesaing media lain dalam memperoleh selera khalayak.

Terkait dengan kemampuan media penyiaran dalam memperoleh selera khalayak, dalam hal ini penulis uraikan beberapa faktor diantaranya adalah program siaran, menjadi tolak ukur dalam keberhasilan yang ditetapkan oleh media siaran.

Program siaran tersebut secara langsung berhubungan erat dengan aspek pemasaran program siaran. Meski tidak kentara, namun dalam aplikasinya di media penyiaran, senantiasa menjadi pemikiran yang tiada akhir yang dilakukan oleh pihak media penyiaran. Berikut beberapa perbedaan media penyiaran dengan media cetak. Hal ini untuk memperjelas kedudukan penyiaran dalam perkembangan industri media.

\begin{tabular}{|c|c|}
\hline $\begin{array}{c}\text { JENIS } \\
\text { MEDIA }\end{array}$ & SIFAT \\
\hline Cetak & $\begin{array}{l}\text { - dapat dibaca, dimana dan } \\
\text { kapan saja } \\
\text { - dapat dibaca berulang-ulang } \\
\text { - daya rangsang rendah } \\
\text { - } \text { pengolahan bisa mekanik, bisa } \\
\text { elektris } \\
\text { - biaya relatif rendah } \\
\text { - daya jangkau terbatas }\end{array}$ \\
\hline Radio & $\begin{array}{l}\text { - } \text { dapat didengar bila siaran } \\
\text { - } \text { dapat didengar kembali bila } \\
\text { diputar kembali } \\
\text { - } \text { daya rangsang rendah } \\
\text { - } \text { elektris } \\
\text { - } \text { relatif murah } \\
\text { - } \text { daya jangkau besar }\end{array}$ \\
\hline Televisi & 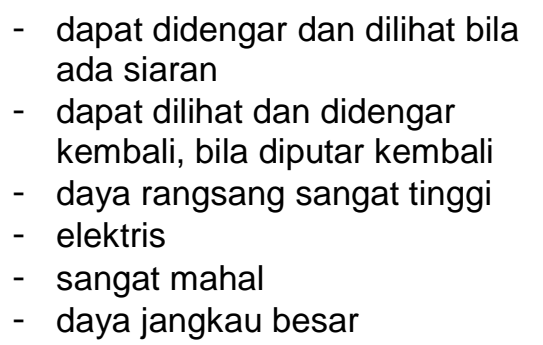 \\
\hline
\end{tabular}

Kembali pada media penyiaran, baik televisi maupun radio, berdasarkan kekuatan media elektronik di atas, terdapat 3 peluang (opportunity) dari aspek pemasaran produk program siaran radio maupun televisi. Yaitu, Strategi Melihat dan menentukan audien untuk Penyiaran:

1. Produk program (product), mencakup nama dan kemasan program

2. Harga program (price), biaya program dan biaya yang akan dikenakan kepada 
pemasang iklan (tarif iklan) pada program yang ditayangkan.

3. Distribusi program (place), pengiriman program dari transmisi ke audien

4. Promosi program (Promotion), proses memberitahu suatu program agar menarik audien.

\section{B. Analisis Khalayak}

Dalam penyelenggaraan penyiaran di stasiun radio maupun televisi, pilot projek atau machine anginenya adalah program siaran. Program siaran berarti acara atau rencana. Program juga merupakan segala hal yang ditampilkan stasiun penyiaran untuk memenuhi kebutuhan audiennya (Morissan, 2008). Menurut Dominick kegiatan programming adalah suatu kegiatan dalam manajemen siaran untuk merencanakan acara siaran dan menyusun atau menempatkannya dalam suatu jadual baik yang bersifat bulanan, mingguan ataupun harian (Nunung Parajarto,2004)

Program siaran selain menjadi faktor utama yang diperhatikan dalam operarisonal siaran, tak jarang juga menjadi permasalahan besar bagi stasiun. Hal ini karena media dihadapkan dengan berbagai persoalan baik internal stasiun sendiri maupun dukungan dari luar. Padahal sumber income radio adalah berasal dari keberhasilan pelaksanaan program siaran.
Faktor manajemen sumber daya manusia penyiaran salah satu contoh permasalahan yang kerap menghambat jalannya roda stasiun radio. Sebagi contoh $\mathrm{RRI}$ yang tersebar di wilayah Indonesia ketika dihadapkan pada pemasaran dan pengembangan usaha, RRI tertatih-tatih dalam mengelola SDM yang ada. Adanya kebutuhan Radio Republik Indonesia yang selama ini bergantung pada pemerintah masih sangat besar. Kini RRI mesti menghadapi persaingan radio swasta yang semakin berkembang.

Masduki (2004) menyebutkan bahwa melihat kepentingan program siaran mesti mempunyai acuan sebagai standar operational prosedure (SOP). Namun jauh sebelum alat bantu itu diterapkan, media penyiaran mempunyai rencana yang matang dalam menentukan target audien sebagai penerima program siaran.

Dalam hal ini target audien didefinisikan sebagai sumber media yang McQuail sebut sebagai kelompok atau publik yang juga merupakan kelompok sosial yang ditarik dalam level masyarakat secara makro. Sementara dalam level mikro, dalam posisi media dipandang sebagai khalayak saluran atau konten yang mana dalam posisi masyarakat saluran atau konten sebagai perangkat kepuasan khalayak atau masyarakat (Denis Mc Quail, 2011). 
Sebagai sumber media, khalayak mendapat perlakuan khusus dari penyelenggara penyiaran baik televisi dan radio. Aktivitas surveipun ke masyarakat baik secara sistematis, acak maupun lebih mendalam mengenai selera masyarakat sedianya dilakukan. Perspektif Budi Sayoga termasuk menentukan tujuan program siaran, genre atau kategori, atau jenis atau format siaran dan segmentasi khalayak (Nunung Parajarto. 2004). Untuk melihat keberhasilan itu, adalah dengan bagaimana besarnya animo pendengar atau penonton pada program siaran yang di produksi. Penentuan arah atau tujuan program siaran tiada lain sebagai cara atau upaya dalam menjaga eksistensi media penyiaran di tengah persaingan bisnis penyiaran yang kian hari kian berkembang. Sehingga ketika program siaran diluncurkan ke penonton atau ke telinga pendengar, stasiun telah mendapat sambutan yang positif sebagaimana yang diharapkan pihak media penyelenggara siaran.

Pendengar yang selalu berubah, dalam jumlah maupun kebutuhan dan keinginan. Menurut Dennis List (2003), bila diurutkan dalam sebuah lingkaran khalayak yang terpapar program siaran, dari posisi 5 ke posisi 1 :
5. Khalayak yang tinggal di luar jangkauan area.

Radio tidak bisa menjangkau mereka, tapi bisa dengan radio streaming (intenet).

4. Khalayak yang tinggal di wilayah sekitar, tapi tidak pernah mendengarkan radio.

Maka stasiun radio harus mampu membuat mereka mengenal dan mendengarkan radio, bukan dengan iklan radio karena mereka tidak mendengarkan radio.

3. Occasional listeners. Pendengar nonreguler.

Agar menjadi khalayak reguler, mereka membutuhkan "program expose". Maka, iklankan acara-acara radio. Membuat promo program di radio sendiri.

\section{Regular listeners}

Menjaga loyalitas khalayak? Bagaimana stasiun radio "memanfaatkan" khalayak? agar pasang iklan, mungkin? Bisa juga mengajak khalayak menjadi relawan atau membantu media semampu mereka. Seperti membentuk organisasi fans radio atau radio fans club. 
1. Pendengar di lingkaran terdalam.

Mereka adalah staf, manajer, produser, dan Volunteer. Mungkin juga keluarganya. Manajemen SDM dan keuangan menjadi penting. Bagaimana mereka bisa tetap setia, termotivasi, dan mampu melahirkan ide-ide pengembangan demi kemajuan radio dan tidak membuat khalayak kecewa.

Mengingat pentingnya kedudukan audien dalam penyelenggaraan penyiaran radio maupun televisi, maka program siaran seperti radio di dominasi oleh satu elemen atau suara yang utama yang dikenal dengan format. Format radio siaran menjadi ciri khas stasiun radio dan tiap stasiun radio mempunyai format siaran yang memiliki ciri-ciri tertentu (Irwanti Said, 2012). Misalnya:

1. Radio Hiburan/ musik

2. Radio informasi

3. Radio campuran

4. Radio Propaganda

5. Radio Religius

6. Radio Anak

7. DII

Sebagai contoh lebih rinci lagi, program hiburan atau musik di radio maupun televisi terbagi dalam beberapa kategori seperti, progam musik, program drama, program humor dan program kuis.

Dalam pemilihan program siaran dan pengembangan siaran, sepenuhnya menjadi kebijakan stasiun radio maupun televisi. Sebab tidak semua format siaran terhimpun dalam satu stasiun penyiaran. Hal ini sebagai upaya pengelola stasiun penyiaran memenuhi kebutuhan khalayaknya. Misalkan radio Prambors yang menggarap program humor dalam siarannya sehingga mempopulerkan Warkop DKI atau seperti radio Kenari image-nya di masyarakat sebagai radio dangdut melayunya Pontianak.

Penentuan program siaran yang nantinya bisa mengikat audien atau khalayak sebagaimana contoh di atas, secara tidak langsung telah menimbulkan citra dan reputasi stasiun penyiaran di masyarakat. Lebih jauh dapat menaikkan rating media tersebut di masyarakat.

Oleh itu, media penyiaran perlu memperhatikan fungsi penataan program siaran yang dilakukan oleh penyelenggara penyiaran (Harley Prayudha, 2004) yaitu:

\section{Fungsi programming berdasarkan penjadwalan}

Pengaturan operasional waktu program siaran diluncurkan. Penjadwalan sangat menitikberatkan kepada kondisi masyarakat sebagi konsumen media penyiaran. Dalam praktiknya masingmasing stasiun menentukan operasional siaran 15 hingga 20 jam, ada pula yang bersiaran selama 24 jam setiap hari. 
Secara umum, penjadwalan siaran terbagi pada:

- Morning Drive adalah waktu pagi berkisar 05.30 atau 06.00 hingga 10.00 pagi

- Day Time, waktu siang. Antara jam 10.00 hingga jam 15.00

- Afternoon Drive. Sore hari antara jam 15.00 hingga 19.00 atau jam 20.00

- Night-time atau waktu malam adalah antara jam 19.00 atau 20.00 hingga tengah malam

- Sementara overnight lewat tengah malam atau dini hari adalah selang waktu antara tengah malam hingga saat Morning Drive.

\section{Fungsi programming, berkesinambungan (Continiuous)}

Tujuan dari program siaran adalah berkesinambungan, artinya, stasiun penyiaran senantiasa mengembangkan jumlah pendengar sekaligus mengikat khalayak hingga tidak henti-hentinya senantiasa bertahan atau tidak berpindah pada stasiun lain melainkan terus pada stasiun radio atau televisi yang menjadi perhatiannya atau yang menjadi kegemaran khalayak penyiaran. Hal ini dalam kenyataannya di lapangan mampu menumbuhkan perhatian khalayak hingga kepada khalayak yang aktif atau pendengar atau penonton fanatik.

\section{Fungsi programming persaingan yang luar biasa (extremely cometitive).}

Dalam pelaksanaannya, iklim kompetisi antar media penyiaran yang memiliki format siaran yang sama atau yang sekarang kian berkembang secara kuantitasnya. Hal ini memungkinkan media penyiaran semakin meningkatkan kualitas siarannya agar menjadi unggul diantara media lainnya. Namun hal ini tidak semudah yang dibayangkan. Butuh kemampuan kreativitas dari prorgram unggulan yang lancarkan ke tengahtengah masyarakat yang menjadi tolak ukurnya. Karena itu, media penyiaran, tidak henti-hentinya mengatur ulang atau melakukan kebijakan yang terkait dengan keinginan khalayaknya atau lebih sederhanya lagi, segera melakukan evaluasi terhadap program siaran yang telah berjalan atau setidaknya melakukan hal-hal yang terkait dengan program siaran yang telah berjalan untuk menyesuaikan dengan kebutuhan berdasarkan potensi wilayah masing-masing di mana stasiun bersiaran. Demikian juga target sasaran dari program siarannya mesti diperhatikan.

\section{Fungsi programming, yaitu menjaga stabilitas dalam jadual program siaran.}

Keadaan ini menjadi hal yang penting juga untuk sebuah stasiun penyiaran yang mana kemudian 
berdampak kepada kemajuan dari stasiun itu sendiri. Sebab tidak semua program siaran yang diluncurkan mampu bertahan di masyarakat. Hal ini terkait dengan promosi atau iklan yang yang menjadi pemasok utama dalam bisnis penyiaran yang menghidupkan stasiun penyiaran. Maka itu program siaran mesti dijalankan secara stabil untuk kemudian mampu menjadi penopang dalam operasional penyiaran lebih panjang dan lebih baik lagi.

\section{Fungsi programming.}

Maksudnya adalah memperoleh ide atau materi kreatif yang bisa didapat dari berbagai sumber yang memungkinkan mampu menghidupkan media penyiaran. $\mathrm{Hal}$ ini terkait dengan pengembangan sumber daya manusia penyiaran yang ada di media penyiaran. Ada banyak tipologi broadcaster dalam suatu stasiun penyiaran. Dalam pandangan Irwanti Said praktisi penyiaran, broadcaster yang kreatif, intelek, komunikatif, rajin, disiplin, motivator tim dalam bekerja dan mampu menjadi contoh adalah diantara pendukung media siaran (Irwanti Said, 2012).

Hasilnya, bentuk-bentuk programprogram baru diharapkan mampu meningkatkan minat pendengar atau penonton. Karena itu, dalam penyelenggaraan penyiaran tidak terlepas dari bagaimana mengatur sumber daya manusia dalam media penyiaran.

\section{Fungsi programming, spekulasi.}

Artinya, media penyiaran dengan program siaran yang dibuatnya bukanlah bersifat statis, melainkan bersifat dinamis yang senantiasa berkembang dari hari ke hari. Maka berbagai strategi dapat dilakukan untuk menaikkan minat khalayak pada stasiun penyiaran. Dengan asumsi bahwa kebutuhan khalayak juga senantiasa berubah sesuai situasi dan kondisi yang terjadi di masyarakat.

Artinya, kebutuhan khalayak makin berkembnag dengan keadaan terkini yang terjadi pada masyarakat yang terus berubah. Maka tidak heran, apabila program siaran tidak sepenuhnya dapat berjalan secara mulus. Bisa saja memunculkan kegagalan dalam proses pelaksanaannya. Disinilah dinamikanya. Kemungkinan akan muncul banyak spekulasi ketika keputusan yang dikeluarkan dalam pengaturan program siaran. Namun bagaimanapun upaya tersebut baik dilakukan untuk memperbaiki sekaligus meningkatkan mutu program siaran. Karena itu membuat progam siaran tidak mesti berpacu pada satu aspek, bisa saja banyak aspek yang dipertimbangkan media penyiaran. Kembali bagaimana langkah strategis yang diambil oleh media 
penyiaran dalam menata program siarannya.

Berikutnya, melihat kondisi audien yang tersebar di kawasan yang berbedabeda secara demografis, psikografis dan latar belakang. Namun pada umumnya khalayak Walaupun pada dasarnya khalayak bersifat sederhana, hiterogenus, pada kebanyakan khalayak bersifat individualistik, sensitif, dan possessive. Pola khalayak juga akan berubah. Kecenderungan citarasa dan kehendak khalayak juga berubah. Kesadaran tentang kondisi khalayak yang demikian ini wajib senantiasa ada dalam pemikiran pihak stasiun televisi maupun radio.

Disinilah muncul kompetisi antar media penyiaran. Bagaimana media penyiaran mampu meramu program baru yang diminati oleh khalayak. Adanya unsur-unsur baru dalam konten program siaran dan mampu memukau khalayak. Makin sadar media penyiaran akan keadaan khalayak yang butuh hal-hal baru dan senantiasa up date dengan perkembangan khalayak, maka semakin cepat media penyiaran mendapat posisi pertama di hati khalayak. Sebaliknya, sekiranya media penyiaran lambat merespon terlebih gagal melihat perubahan yang terjadi pada khalayak, maka bukan tidak mungkin, suatu media penyiaran akan ditinggalkan khalayaknya dan media penyiaran semakin tersingkir dari dunia khalayak.

Selanjutnya, jika berdasarkan sebaran audien secara geografis, yang berada di berbagai daerah baik kota maupun desa, tentunya memiliki karakter yang berbeda pula. Karakter audien menyangkut pada pola daya beli atau konsumsi juga cita rasa. Hal ini akan menjadi pertimbangan dalam menetapkan program siaran.

Sementara berdasarkan kondisi demografis, khayalak dari media penyiaran, berdasarkan kepada perbedaan jenis kelamin, usia, pendidikan, jenis pekerjaan dll, dan sebagai contoh, data khalayak berdasarkan usia.

Khalayak berdasarkan usia pada umumnya terbagi pada beberapa katagori, seperti dewasa, remaja dan anak-anak. Pengelompokan ini, berguna bagi media penyiaran dalam menentukan jenis program siaran yang sesuai dengan kebiasaan dan kebutuhan masing-masing golongan usia. Contoh program sinetron atau infotaiment masih menjadi pilihan bagi kelompok orang dewasa. Adapun anakanak pada umumnya cenderung berminat pada film kartun atau animasi. Segmentasi usia menurut standar Amerika Serikat yang ditulis Morrisan (2008). 


\begin{tabular}{|c|c|}
\hline No & Kelompok usia \\
\hline 1 & $0-6$ Tahun \\
\hline 2 & $6-11$ Tahun \\
\hline 3 & $12-17$ Tahun \\
\hline 4 & $18-24$ Tahunan \\
\hline 5 & $25-34$ Tahun \\
\hline
\end{tabular}

Oleh karena itu data demografis menjadi bahan bagi media penyiaran dalam menentukan program yang sesuai dengan khalayak yang disasar terlebih dalam menetapkan strategi pemasaran atau iklan yang bisa menarik pendengar ataupun penonton. Berdasarkan kondisi sosial budaya, keadaan khalayak berdasarkan suku bangsa, Adat, tingkah laku, pakaian, warna, bentuk, bahasa.

Masduki melihat khalayak dari segi partisipasi terhadap acara siaran, ada empat tipologi pendengar yakni (Masduki, 2004) seperti tergambar dalam tabel berikut:

\begin{tabular}{|l|l|}
\hline \multicolumn{1}{|c|}{ Tipologi } & \multicolumn{1}{|c|}{ Pengertian } \\
\hline Pendengar & $\begin{array}{l}\text { Bersifat kebetulan. Tidak } \\
\text { berencana mendengarkan } \\
\text { siaran radio atau acara } \\
\text { tertentu. Perhatian mudah } \\
\text { teralih pada aktivitas lain. }\end{array}$ \\
\hline $\begin{array}{l}\text { Pendengar } \\
\text { Pasif }\end{array}$ & $\begin{array}{l}\text { Suka mendengarkan siaran } \\
\text { radio untuk mengisi waktu } \\
\text { luang dan menghibur diri, } \\
\text { menjadikan radio sebagai } \\
\text { teman biasa. }\end{array}$ \\
\hline $\begin{array}{l}\text { Pendengar } \\
\text { Selektif }\end{array}$ & $\begin{array}{l}\text { Mendengar siaran radio } \\
\text { pada jam atau acara } \\
\text { tertentu saja, fanatik pada }\end{array}$ \\
\hline
\end{tabular}

\begin{tabular}{|c|c|}
\hline & $\begin{array}{l}\text { sebuah acara atau penyiar } \\
\text { tertentu, menyediakan } \\
\text { waktu khusus untuk } \\
\text { mendengarkannya. }\end{array}$ \\
\hline $\begin{array}{l}\text { Pendengar } \\
\text { Aktif }\end{array}$ & $\begin{array}{l}\text { Secara reguler tak terbatas } \\
\text { mendengarkan siaran } \\
\text { radio, apapun, dimanapun, } \\
\text { dan aktif berinteraksi } \\
\text { melalui telepon. Radio } \\
\text { menjadi sahabat utama, } \\
\text { tidak hanya pada waktu } \\
\text { luang. }\end{array}$ \\
\hline
\end{tabular}

\section{Merancang Program}

Berdasarkan fenomena khalayak di atas, secara umum strategi merancang program siaran setidaknya berangkat dari riset audien yang dilakukan oleh lembaga penyelenggara penyiaran. Jika melihat pengalaman penyiaran di Indonesia khususnya pada penetapan rating penonton Televisi. Riset audien untuk untuk rating pada lembaga penyiaran seprti yang kerap dilakukan oleh lembaga riset seperti A.C Nielsen dan Arbitron.

Rating sendiri merupakan perkiraan komparatif dari jumlah pesawat televisi yang sedang digunakan pada suatu wilayah siaran tertentu (head dan sterling). Bagi penetapan program perdana yang akan diluncurkan ke masyarakat, riset audien atau penelitian tindakan khalayak terhadap pelaksanaan lembaga penyiaran dalam pandangan Hidajanto Djamal dan 
Andi Fachruddin dapat dilakukan dengan riset non rating. Tujuannya untuk menguji coba program sebelum diproduksi. Hal ini dilakukan sebagai acuan dalam mempersiapkan secara matang program siaran yang akan diberikan kepada khalayak, Hidajanto Djamal dan Andi Fachruddin.2011). Lebih terperinci lagi proses penetapan program siaran dapat diperoleh dari:

$\checkmark$ Ide (dari lembaga penyelenggara penyiaran

$\checkmark$ P3 SPS (Pedoman Perilaku Penyiaran dan Standar Program Siaran)

$\checkmark$ Program Stasiun lain

$\checkmark$ Kode etik Penyiaran

$\checkmark$ Merumuskan Program yang direncanakan

$\checkmark$ Menetapkan riset audien baik rating atau non rating

$\checkmark$ Menetapkan program

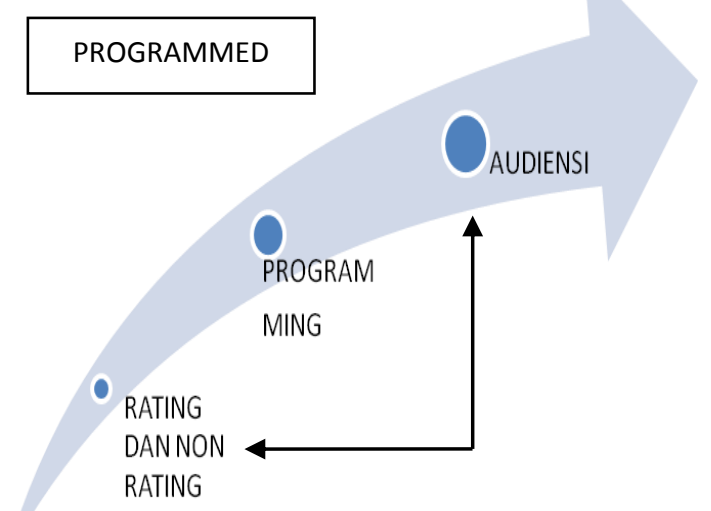

Diagram Kesisteman Programming

Sumber: Hidajanto Djamal dan Andi achruddin.2011
Konsep pelaksanaan riset non rating khususnya adalah untuk mengetahui tindakan audien baik itu menghidupkan saluran atau kanal, memindahkan dan mematikan saluran atau kanal TV atau radio. Dalam beberapa metode pengumpulan data, yang dapat dilakukan seperti berikut ini:

\section{- Catatan}

Penonton atau pendengar diminta mencatat penggunaan pesawat tv/radio di rumah setiap hari. Untuk TV menurut Morissan (2008) tidak hanya mencatat program televisi yang ditonton tapi juga informasi demografis yang menonton termasuk tamu/tetangga yang ikut nonton. Untuk radio:

pendengar diminta mencatat waktu mendengarkan siaran radio dan stasiun radio yang didengar.

\section{- Alat pemantau (recordimeter).}

Dipasang di pesawat tv dapat
mencatat informasi tentang program
tayangan yang ditonton suatu rumah
tangga secara lengkap menyeluruh
(pelopor ac nielcen)

- Telephone coincidental method (tcm)

Menghubungi penonton/pendengar yang tengah menonton tv /mendengarkan 
siaran radio. Pada metode tcm, lebih mendapat jawaban spontan mengenai:

- Menonton/mendengar atau tidak

- Stasiun tv/radio apa yang tengah dilihat/ didengar

- Siapa saja yang ikut menonton/mendengarkan siaran

\section{- Focus Groups (FG)}

Untuk memperkirakan pengaruh dari suatu program yang baru, mengumpulkan pandangan-pandangan untuk memperbaiki cara.

\section{- Riset Telepon}

Dsb

\section{- Telephone recall}

Melakukan wawancara melalui telepon dengan isi seperti pada tcm, namun dilakukan dalam suatu periode tertentu untuk mengurangi kesalahan ingatan responden

\section{- Wawancara langsung}

Mendatangi rumah responden. sering digunakan untuk riset non rating

Sementara untuk media radio, riset dilakukan dengan melihat tipe format siaran, pilihan musik, campuran, musik yang ditinggalkan, perceptual call-outs (riset untuk selain musik) dan life style analysis (riset gaya hidup pendengar).
Dalam perspektif manajemen perencanaan berarti posisi program (menyangkut peranan aktif, sadar dan rasional yang dimainkan oleh manajemen lembaga penyelenggara penyiaran dalam perumusan tujuan organisasi) umum untuk pencapaian tujuan-tujuan organisasi dalam pelaksanaan misi.

Berikutnya, terdapat 10 strategi dalam merancang program yang digunakan stasiun penyiaran di dunia (Hidajanto Djamal, Andi Fachruddin, 2011) yaitu:

1. Dayparting

Pembagian slot waktu setiap hari yang didasarkan pada target audien

2. Theming

Penentuan tema tertentu berdasarkan hari khusus seperti hari minggu

3. Stripping

Penayangan suatu program berjaringan yang ditayangkan secara tidak langsung (delay programme) biasa disebut program sindikasi.

4. Stacking

Pengelompokkan program yang sama tema atau mirip dalam rangka melihat penonton selama penayangan satu program dengan progam berikutnya.

5. Counterprogramming

Program tandingan terhadap program yang behasil dari stasiun penyiaran lain pada periode tayang tertentu 
dengan tujuan menarik audien dari stasiun pesaing

6. Bridging

Dalam rangka mencegah audien pindah saluran dam satu jeda waktu

7. Tentpoling

Langkah perencanaan slot waktu bagi program acara yang baru. Penempatan program baru ini akan membuat audien berkesempatan melihat tayangan cuplikannya.

8. Hammocking

Langkah perencanaan slot waktu yang mirip. Tapi program tersebut ditempatkan di antara 2 program unggulan. Tujuannya melihat tayangan cuplikannya, sehingga diharapkan audien tetap di kanal tersebut.

9. Crossprogramming

Pemilihan jenis program berikut dalam urutan jadualnya dan penayangan satu program yang mempunyai relevansi tema.

10. Hotswitching

Penentuan jeda komersial yang tepat oleg programme pada satu program sedemikian rupa, sehingga audien tak beralih kanal.

Format siaran menyangkut pendengar

\section{Penutup}

Mengingat betapa pentingnya progam siaran dalam sebuah lembaga penyelenggara penyiaran, dan secara ekonomi, pendengar adalah konsumen produk siaran. Hal ini sudah tentu membuat ritme kerja dari sebuah lembaga tersebut lebih fokus dan lebih berkonsentrasi dam memperhatikan proses awal hingga produk siaran diterima khalayak. Terlebih hal ini dikaitkan dengan kualitas produksi program yang dikeluarkan. Maka tak heran media penyiaran mempertimbangkan banyak hal sebelum menetapkan konten siaran yang nantinya diharapkan dapat menyedot perhatian khalayak.

Pertimbangan penetepan program siaran seperti saran Morissan (2008) tak jauh dari kondisi audien seperti ketersediaan audien, kebiasaannya, ketertarikan audien. Dalam pandangan penulis, selain dari pendapat tersebut, seluruh atribut yang berhubungan dengan peningkatan kualitas program itu sendiri menjadi tantangan bagi penyelenggara penyiaran dalam memahami kekuatan manajemen program secara menyeluruh tanpa terkecuali memperhitungkan ketertarikan pemasang iklan dan tentunya termasuk kreativitas sumber daya manusia yang terlibat dalam media penyiaran.

\section{E. Daftar Pustaaka}

Nunung Parajarto. Editor. 2004. Komunikasi, Negara dan Masyarakat. Yogyakarta: Lafadl Offet 
Denis Mc Quail, 2011. Teori Komunikasi

Massa. Jakarta: Salemba Humanika

Harley Prayudha. Radio. Suatu Pengantar.

Malang: Bayumedia Publishing

Masduki, 2004. Menjadi Broadcaster

Profesional, Yogyakarta: LkiS.

Morrisan, MA, 2008. Manajemen Media

Penyiaran; Strategi Mengelola Radio

Dennis List. http:// www.romelteamedia.

com/2014/04/strategi-program-siaran

-radio. html. Diakses Agustus 2015

Hidajanto Djamal, Andi Fachruddin.2011.

Dasar-dasar Penyiaran. Jakarta:

Kencana Prenada Media Group.

Irwanti Said. 2012. Fungsi Sosial Siaran

Radio. Makassar: Alauddin University

Press 